\title{
Intracranial extramedullary hematopoiesis associated with multiple myeloma
}

Figure Brain CT scan findings in intracranial extramedullary hematopoiesis

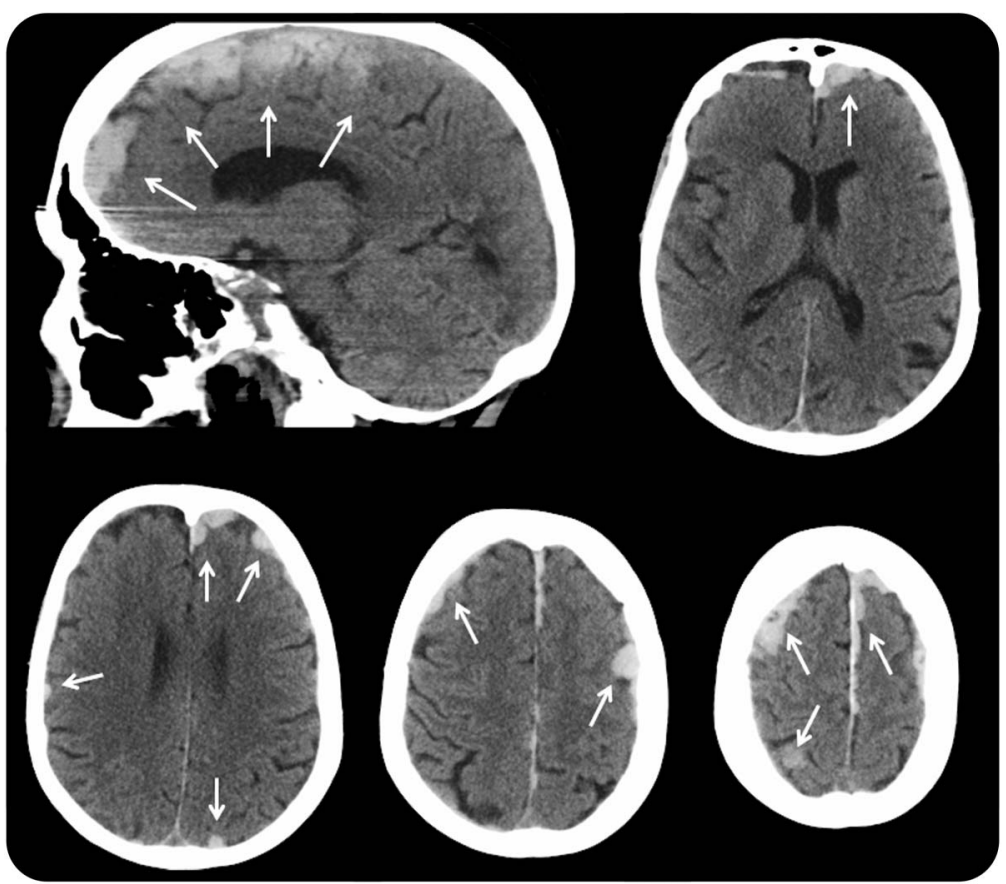

Brain CT scan, sagittal and axial views, showing multiple hyperdense extra-axial foci (arrows) surrounding the falx cerebri and dural convexity, and compressing the cortex of both cerebral hemispheres.

A 77-year-old woman with multiple myeloma for 5 years presented with obtundation, drowsiness, and disorientation over 15 days. Complete blood count revealed thrombocytopenia $(25,000 / \mu \mathrm{L})$. A brain CT disclosed multiple extra-axial hyperdense foci without bone destruction. Differential diagnosis included tumors (meningiomas, leukemia), subdural hematomas, and intracranial hemorrhages; the lesion's multiplicity and morphology were consistent with intracranial extramedullary hematopoiesis (IEH) (figure). Despite platelet transfusions, she died 2 days later of alveolar hemorrhage. Autopsy confirmed IEH and excluded erythropoiesis, reported in subdural hematomas. The formation of blood cells outside the bone marrow is usually related to anemia or lymphoproliferative disorders and is uncommon in multiple myeloma. ${ }^{1}$ IEH can cause seizures, hydrocephalus, or cognitive changes. ${ }^{2}$

Jose-Alberto Palma, MD, Pablo D. Dominguez, MD, Mario Riverol, MD, PhD

From the Departments of Neurology (J.-A.P., M.R.) and Radiology (P.D.D.), University Clinic of Navarra, Pamplona, Spain. Author contributions: Drafting/revising the manuscript for content: J.-A.P., P.D.D., M.R. Study concept or design: J.-A.P., M.R. Analysis or interpretation of data: P.D.D., M.R. Acquisition of data: P.D.D.

Study funding: No targeted funding reported.

Disclosure: The authors report no disclosures relevant to the manuscript. Go to Neurology.org for full disclosures.

Correspondence to Dr.Riverol:mriverol@unav.es

1. Zherebitskiy V, Morales C, Del Bigio MR. Extramedullary hematopoiesis involving the central nervous system and surrounding structures. Hum Pathol 2011;42:1524-1530.

2. Buetow PC, Perry JJ, Geyer CA. Gd-DTPA enhancement in CNS extramedullary hematopoiesis. AJNR Am J Neuroradiol 1990; 11:411-412. 


\section{Neurology}

\section{Intracranial extramedullary hematopoiesis associated with multiple myeloma}

Jose-Alberto Palma, Pablo D. Dominguez and Mario Riverol

Neurology 2013;80;1620

DOI 10.1212/WNL.0b013e31828f1899

\section{This information is current as of April 22, 2013}

\section{Updated Information \& Services}

References

Subspecialty Collections

Permissions \& Licensing

Reprints including high resolution figures, can be found at: http://n.neurology.org/content/80/17/1620.full

This article cites 2 articles, 1 of which you can access for free at: http://n.neurology.org/content/80/17/1620.full\#ref-list-1

This article, along with others on similar topics, appears in the following collection(s):

\section{CT}

http://n.neurology.org/cgi/collection/ct

Metastatic tumor

http://n.neurology.org/cgi/collection/metastatic_tumor

Information about reproducing this article in parts (figures,tables) or in its entirety can be found online at:

http://www.neurology.org/about/about_the_journal\#permissions

Information about ordering reprints can be found online:

http://n.neurology.org/subscribers/advertise

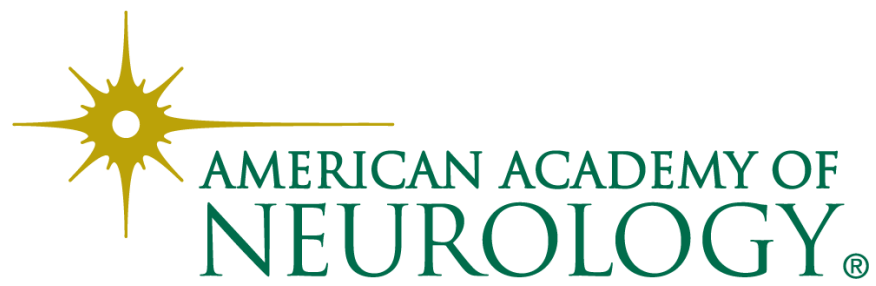

